\title{
Genetic Diversity in the Plant-Pathogenic Fungus Fusarium oxysporum
}

\author{
H. C. Kistler
}

P.O. Box 110680, Plant Pathology Department, University of Florida, Gainesville 32611-0680.

Accepted for publication 2 January 1997.

One of the problems encountered when studying the population genetics of fungal plant pathogens is defining what constitutes a "population" of the fungus. This problem is compounded for $\mathrm{Fu}$ sarium oxysporum Schlechtend.:Fr. and other anamorphic fungi, for which even clear delineation of species is lacking. To address questions such as migration and gene flow between populations of F. oxysporum, we first must have some reasonable expectation that genetic exchange is possible between the populations or, at least, that the populations belong to a single species. Genetic diversity studies on $F$. oxysporum are beginning to define populations and address the question of the species concept for this important plant-pathogenic fungus.

This review seeks to summarize some of the findings of genetic diversity studies on $F$. oxysporum that have been conducted in the last 10 years. It is not meant to be a comprehensive review of the literature but rather a reflection on some of the common approaches, assumptions, and findings in the field. First, the species and subspecific categories that have been the focus of these studies will be described. Second, the questions being asked by these studies will be summarized. Third, potential topics for future research will be discussed.

\section{F. oxysporum: Species and Subspecific Categories}

F. oxysporum is a common, widespread fungus found in soil. Although the species has been defined by morphology of asexual reproductive structures, considerable variation occurs in these features. The species was placed in the section (Gruppe) Elegans by Wollenweber and Reinking (92) along with nine other species in three subsections (Untergruppen). Nonetheless the morphological divisions within section Elegans are small, and the features themselves highly variable and subject to environmental influence (78). For this reason, Snyder and Hanson (88) collapsed section Elegans into a single species: F. oxysporum. However, these authors also recognized true variants within the species, at least with respect to host plant species specialization. Although many or most isolates of the fungus may be nonpathogenic soil inhabitants (3), the concept of form or specialized form (forma specialis) arose to delineate morphologically similar or indistinguishable isolates having the ability to cause disease on different plants.

\section{Forma Specialis}

F. oxysporum has received considerable attention from plant pathologists over the past 80 years because of its ability to cause vascular wilt or root rot diseases on a wide range of plants. Despite the broad host range of the species as a whole, host special-

Corresponding author: H. C. Kistler; E-mail address: hck@gnv.ifas.ufl.edu

Publication no. P-1997-0131-010

(C) 1997 The American Phytopathological Society ization of individual isolates is more circumscribed. Isolates with the same or similar host ranges are assigned to a forma specialis, and more than 70 formae speciales have been described $(7,12)$. More often than not, host range is restricted to a few plant species. For example, although many plants may be symptomless carriers of the fungus (45), F. oxysporum f. sp. lycopersici causes disease only in plants of the tomato genus Lycopersicon (86). However, some formae speciales have broader host ranges, such as $F$. oxysporum $\mathrm{f}$. sp. radicislycopersici, which at least in greenhouse studies can cause disease on hosts from several other plant families as well as tomato $(70,86)$.

The categorization of strains by host range may or may not lead to a natural subdivision within the species. The assumption often made is that isolates with shared host range, and thus within the same forma specialis, are more similar genetically than isolates with other host specificities. The evolutionary interpretation resulting from this assumption is that formae speciales are monophyletic and that isolates with a shared host range are likely derived from a single, particularly successful pathogenic genotype. This underlying assumption now can be tested with genetic markers independent of pathogenicity.

\section{Vegetative Compatibility Groups (VCG)}

During the mid-1980s, Puhalla (84) first attempted to distinguish and classify strains of $F$. oxysporum by purely genetic means, rather than by morphology and/or host range. Using a technique previously applied to Aspergillus, Puhalla created auxotrophic mutants unable to use nitrate as a sole nitrogen source. These nit mutants, affected at different steps in the pathway involved in nitrogen reduction, were paired on minimal medium. If pairs of isolates fused to produce a heterokaryon, complementation resulted in wild-type growth. Such isolates were determined to be in the same VCG. The four- or five-digit numbering system for VCG designation, proposed by Puhalla (84), is still in use.

Knowledge of vegetative compatibility is important for two reasons. First, in some instances it may be a relatively objective test for genetic similarity, because in ascomycetes with better characterized genetic systems vegetative compatibility is known to be the result of the action of alleles at several distinct loci. For example, in Neurospora crassa heterokaryon compatibility is conferred by at least 11 loci dispersed on 5 chromosomes (31). For two strains of $N$. crassa to be compatible, alleles at all loci must be identical. Thus, the more closely related two isolates are genetically the more likely they are to be vegetatively compatible. By inference, only isolates of $F$. oxysporum very similar genetically (and isoallelic at all presumptive heterokaryon compatibility loci) would be members of the same VCG. Therefore, VCG determination may reflect genetic similarities, although not the degree of genetic differences, among isolates of the species.

Second, and perhaps a more important aspect of VCG, is what it might imply about the reproductive strategy and, ultimately, the 
population structure of the fungus. F. oxysporum is presumed to reproduce strictly by asexual means. Although some isolates may produce sterile stromatic tissue suggestive of a Gibberella-like perithecium (12) and the species groups into a well-supported clade containing fungi with known Gibberella teleomorphs, based on DNA sequence analysis of the gene for nuclear large ribosomal RNA (rDNA) (15), no sexual spores or authentic meiotic apparatus has ever been associated with $F$. oxysporum (33). If asexual reproduction is the rule, strains related by clonal descent should be within the same VCG, because clonally derived strains would be isogenic, or nearly so, and, therefore, vegetatively compatible (unless they happen to be vegetatively self-incompatible [61]). Additionally, isolates within separate clonal lineages and in different VCGs might then be isolated genetically due to vegetative incompatibility. Clonal reproduction and, more importantly, the lack of meiotic recombination would greatly limit or preclude reassortment of genes for heterokaryon incompatibility. Indeed, a population structure of F. oxysporum consisting of distinct clonal lineages corresponding to distinct VCGs suggests the absence of genetic recombination between members of those VCGs/lineages.

\section{Pathogenic Races}

Finally, some mention should be made of races. Races of $F$. oxysporum have been defined inconsistently. In some instances, races correspond to cultivar-level specificity of the host genotype. This definition of race is the most common in plant pathology and is consistent with cultivar selectivity, which is often determined by single genes in the host (e.g., races 1 and 2 of $F$. oxysporum $\mathrm{f}$. sp. lycopersici and the corresponding I and I-2 genes in tomato $[43,89])$. However, in other instances race has been defined by the selectivity of isolates to distinct plant species. For example, Armstrong and Armstrong (7) considered all crucifer-infecting isolates to be members of forma specialis conglutinans and placed cabbage- and radish-infecting isolates in races 1 and 2 respectively, while putting Matthiola-infecting isolates in races 3 or 4 depending on cultivar-level selectivity (6). Bosland and Williams $(13,14)$ placed isolates with different host-species selectivity into separate formae speciales: conglutinans for those causing disease on cabbage, raphani for those on radish, and matthioli for those on Matthiola. Race designation, thus, was reserved for isolates with specificity to particular genotypes within a plant species. For example, older cabbage-infecting isolates of $F$. oxysporum f. sp. conglutinans were called race 1 , while those that could overcome monogenic, type A resistance in cabbage (as opposed to radishinfecting isolates) were called race 2 (85). Isolates with differing specificity toward Matthiola genotypes were called $F$. oxysporum f. sp. matthioli races 1 and 2 (85). For consistency, it would be helpful to limit usage of the term race to describe cultivar-level specialization.

\section{Is $F$. oxysporum a Species?}

As stated previously, F. oxysporum is a large, diverse taxonomic unit. Most genetic diversity studies of the fungus have sought as an initial goal more stable and reliable markers for delineation of the species and subspecific rankings. These studies have used VCGs, isozymes, DNA fingerprinting, restriction fragment length polymorphisms (RFLPs), random amplified polymorphic DNAs (RAPDs), electrophoretic karyotype (EK), and DNA sequence analysis as the basis for comparison of individual isolates. It is beyond the scope of this review to point out the strengths and weaknesses of these approaches. Methodologies and sampling strategies are discussed by McDonald in the introductory paper of this symposium and elsewhere $(15,21,64,68)$. However, each technique has provided a valuable and mostly consistent view of the species.

The first fundamental question posed by genetic diversity studies of $F$. oxysporum is whether $F$. oxysporum can be considered a species. Because no known sexual stage of the fungus is available, the concept of a biological species is not applicable. Practically, given a broad latitude for genetic variation in conidium shape, size, sporulation, and cultural morphology, many contemporary workers consider $F$. oxysporum a distinct morphological species. Likewise, DNA sequence analysis of a portion of the gene for large subunit rDNA indicated identical sequences for 10 isolates of $F$. oxysporum, whereas an isolate of $F$. oxysporum var. redolens differed by 4 of $352 \mathrm{nt}$ (38). (Wollenweber and Reinking [92], however, considered $F$. oxysporum var. redolens a distinct species within section Elegans [i.e., F. redolens]). Sequences from $F$. oxysporum isolates grouped into a fairly well-supported clade compared to sequences from other Fusarium species (15). However, these data lacked resolution sufficient to distinguish species and did not resolve the biological species within the G. fujikuroi complex (60, 80). (Unfortunately, analysis of the potentially more informative internal transcribed spacer [ITS] regions of the ribosomal repeat indicates that this region gives data incongruent with all other molecular and genetic information, and as a result, it is problematic for delineating Fusarium spp. [30,79,80]). Thus, initial DNA sequence comparisons were not inconsistent with the idea that $F$. oxysporum is a valid species.

However, more recent work by Glass and Donaldson (30) is at odds with this conclusion. Their goal initially was to develop a method for identifying isolates of different species of Fusarium found in seeds, roots, and soil associated with conifer trees (primarily Pseudotsuga menziesii) in the Pacific Northwest and British Columbia. A technique was developed that uses oligonucleotide primers to amplify conserved sequences within genes (e.g., histones, $\beta$-tubulin, and ITS region of the rDNA) found in all filamentous fungi (30). The primer sequences flanked variable domains of the conserved genes, so restriction enzyme analysis of the polymerase chain reaction (PCR)-amplified regions detected RFLPs among the isolates analyzed. When this technique was applied to Fusarium cultures associated with conifers, isolates could be identified to the species level with a small number of PCR amplification and restriction enzyme digestion combinations (20). Unexpectedly, the RFLP diversity detected by this method was much greater for $F$. oxysporum than for isolates of other Fusarium species, and cluster analysis placed isolates of $F$. oxysporum in distinct branches of the tree. However, as the authors (20) correctly pointed out, this technique was developed for species identification, not for phylogenetic analysis, and the statistical strength of the conclusions was not reported. Still, using some of the same isolates, gene phylogenies inferred from the DNA sequence of $\beta$ tubulin gene introns, the small subunit mitochondrial rDNA, and the large subunit nuclear rDNA suggest $F$. oxysporum, as currently defined, is actually a species complex (80) consisting of at least five phylogenetically distinct species. Future population studies of F. oxysporum, therefore, must address the likelihood that different isolates of the morphologically defined species are well separated and genetically distinct.

\section{Genetic Diversity Studies on Formae Speciales of $\boldsymbol{F}$. oxysporum}

Other important problems being addressed by genetic diversity studies are the degree of genetic diversity that exists among subspecific categories and whether there is a correlation between pathogenic phenotype and genotype. Such a correlation might be expected based on the assumptions that (i) formae speciales are monophyletic and (ii) $F$. oxysporum is a completely clonally reproducing microorganism. However, when pathotypes (either forma specialis or race) have been considered, there often has been no clear-cut association between these and genotypes determined by RFLPs, RAPDs, or DNA fingerprints.

Genetic diversity studies have been conducted for a large number of formae speciales and are presented in Table 1. For the sake of brevity, studies that solely assigned isolates to VCG are not included in this list. Most studies have focused on genetic variation within a single forma specialis and have adopted a phylogenetic approach to analyze diversity. This approach is useful for 
clonally reproducing organisms in which lineage-specific mutations occur and are maintained without recombination into other genetic backgrounds. The lineages of the pathogen and their ancestry, as a result, can be represented accurately by phylogenetic trees.

Most of the studies listed in Table 1 focus on single formae speciales, so the relationship among isolates in different formae speciales usually has not been addressed. This approach probably was taken because the researchers often were plant pathologists interested in a single disease or crop. Undoubtedly, this type of analysis also was spurred by early reports that isolates within a forma specialis were highly uniform and could be easily distinguished based on VCG and RFLP data. Many of these early reports, however, sampled only limited numbers of isolates and few genetic loci.

\section{Do Clonal Lineages Align with VCGs Within a Forma Specialis?}

More recent work has indicated that isolates within some formae speciales are indeed genetically very similar and fall into a single VCG. An excellent example is F. oxysporum f. sp. albedinis, cause of Bayoud disease of date palm, which is restricted to Morocco and oases of the Algerian Sahara. A collection of 120 isolates, representing the entire geographic range of the pathogen, all belong to a single VCG, and no RFLPs were noted for the mitochondrial DNA (mtDNA) haplotype or the major nuclear rDNA repeat (27). DNA polymorphisms associated with RAPDs easily distinguished isolates of $F$. oxysporum $\mathrm{f}$. sp. albedinis from nonpathogenic $F$. oxysporum isolates from the rhizosphere or roots of date palm (28), but little diversity was noted within the forma specialis using this technique (27). Only hypervariable sequences associated with the F. oxysporum transposable element Fot1 (18) were able to readily distinguish genotypes within forma specialis albedinis (27). However, of the 120 isolates examined, only 52 fingerprint patterns were detected, and each shared at least $80 \%$ similarity based on Jaccard similarity coefficients. These results indicate $F$. oxysporum f. sp. albedinis consists of a single clonal lineage corresponding to a single VCG.

More commonly, formae speciales consist of isolates within two or more VCGs. For example, a study of 115 isolates of the tomato wilt pathogen $F$. oxysporum $\mathrm{f}$. sp. lycopersici from a worldwide collection revealed one major and two minor VCGs (designated 0030, 0031, and 0032, respectively) as well as a large number of isolates that did not form heterokaryons with other isolates and, thus, could not be placed in a VCG (22). The latter isolates, assigned to VCG 003- were heterokaryon self-incompatible. Coef-

TABLE 1. Genetic diversity studies on formae speciales of Fusarium oxysporum

\begin{tabular}{llll}
\hline Forma specialis & \multicolumn{1}{c}{ Method of analysis $^{\mathrm{a}}$} & \multicolumn{1}{c}{ References } \\
\hline albedinis & FP, RFLP, RAPD, VCG & $27,28,90$ \\
ciceris & RFLP, VCG & 81 \\
conglutinans & FP, IS, PL, RFLP, VCG & $13,39,52,54,56$ \\
cubense & EK, FP, IS, RFLP, RAPD, & \\
& VCG & $9,11,56,57,73,82,83$ \\
cucumerinum & FP & 77 \\
cyclaminis & FP, RFLP, VCG & 93 \\
dianthi & EK, FP, RAPD, VCG & $1,46,65-67,74$ \\
elaeidis & RFLP, VCG & 29 \\
gladioli & FP, RAPD, VCG & 71,72 \\
lycopersici & IS, RAPD, RFLP, VCG & $22-24$ \\
melonis & FP, RFLP, SEQ, VCG & $3-5,34,35,41,42,48,77$ \\
niveum & EK, FP, RFLP, VCG & $50,51,59,77$ \\
pisi & FP, RAPD, VCG & $10,16,37,91$ \\
radicis-lycopersici & RFLP, VCG & 49 \\
raphani & FP, IS, PL, RFLP, VCG & $13,39,52,54,56$ \\
vasinfectum & RAPD, RFLP, VCG & $8,26,47$ \\
\hline
\end{tabular}

${ }^{\mathrm{a}} \mathrm{EK}=$ electrophoretic karyotyping, $\mathrm{FP}=\mathrm{DNA}$ fingerprinting, $\mathrm{IS}=$ isozyme analysis, $\mathrm{PL}=$ plasmid DNA profile, RFLP $=$ restriction fragment length polymorphism, RAPD = randomly amplified polymorphic DNA, SEQ = DNA sequence comparison, $\mathrm{VCG}=$ vegetative compatibility grouping. ficients of similarity determined by simple band matching of RFLP data (using 50 anonymous, single-copy clones) showed that the VCG 003 - isolates generally were 85 to $>90 \%$ similar to themselves or other isolates within the three other VCGs. Phenetic analysis of the distance matrix grouped isolates according to the three largest VCGs (and associated 003- isolates) and a fourth branch consisting entirely of VCG 003- isolates. VCG, therefore, is a good predictor of genetic similarity based on RFLP analysis. However, difficulties arise when isolates cannot be assigned easily to a VCG.

The situation of VCGs within $F$. oxysporum f. sp. cubense is even more complex. At least 16 VCGs have been described within a worldwide collection of more than 600 isolates of this forma specialis $(82,83)$. However, a sampling of 165 isolates within these 16 VCGs revealed only 72 multilocus haplotypes, based on the analysis of 19 anonymous, single-copy RFLPs (R. Koenig, R. C. Ploetz, and H. C. Kistler, unpublished data). The effect of clonal reproduction in $F$. oxysporum f. sp. cubense was inferred by widespread geographic distribution of uniform multilocus haplotypes, a paucity of recombinant genotypes, and significant clone-corrected gametic disequilibrium at 34 of 36 pairs of loci tested. The haplotypes were assigned to 10 distinct clonal lineages; lineages generally aligned with VCG, but exceptions occurred. Although some lineages consisted only of isolates within a single VCG, the two largest clonal lineages contained isolates in more than one VCG. VCG was predictive for clonal lineage in $\sim 98 \%$ of the $F$. oxysporum $\mathrm{f}$. sp. cubense isolates examined.

Similar observations have been made for isolates within $F$. oxysporum f. sp. melonis. Appel and Gordon $(3,4)$ sampled populations of pathogenic and nonpathogenic isolates of $F$. oxysporum from soils in Maryland and California. Isolates were assigned to VCGs and grouped according to restriction maps of mtDNA and the intergenic spacer (IGS) region of the nuclear rDNA. In general, VCGs were aligned with distinctive mtDNA and IGS haplotypes, but a few exceptions were noted. In one case, a pathogenic isolate in VCG 0131 shared the mtDNA and IGS haplotype characteristics of pathogenic isolates from VCG 0134. Several other examples showed that nonpathogenic isolates could be vegetatively compatible with pathogenic isolates but differed in their IGS and/or mtDNA haplotype. Therefore, although VCGs very often are consistent with underlying genetic similarities among strains, this correlation is not absolute, at least in instances in which both pathogenic and nonpathogenic isolates are considered.

\section{Are Formae Speciales Monophyletic?}

Recent findings from genetic diversity studies also suggest that certain isolates within a forma specialis may be less genetically similar to each other than to nonpathogenic isolates or isolates in other formae speciales. These observations are surprising and should be controversial because they challenge the assumption that formae speciales are monophyletic and suggest that certain formae speciales should not be viewed as single natural units within the species. Parsimony analysis of differences in mtDNA haplotypes of $F$. oxysporum f. sp. melonis indicated that certain pathogenic isolates were more closely related to nonpathogenic isolates than they were to each other (3). However, this conclusion was not supported by further sequence analysis of the IGS region from the same isolates (5). Nevertheless, phenetic analyses of single-copy (presumably nuclear) DNA polymorphisms among isolates of $F$. oxysporum f. sp. lycopersici, radicis-lycopersici, niveum, and $\mathrm{cu}$ bense failed to support the hypothesis that all isolates assigned to a forma specialis were more closely related to each other than isolates belonging to different formae speciales (T. Katan, R. Koenig, R. C. Ploetz, and H. C. Kistler, unpublished data).

\section{Does Race Align with Clonal Lineage?}

As previously stated, if $F$. oxysporum multiplies solely or largely by clonal, asexual reproduction, one of the expectations is cotrans- 
mission of unrelated neutral genetic markers. This expectation has been met in many instances, for example, by the previously mentioned correlation among VCGs, mtDNAs, and nuclear haplotypes. Even variation in EK, as measured by apparent chromosome number and genome size, has been shown to be highly correlated to presumptive clonal lineage (VCG) in F. oxysporum f. sp. cubense (11).

Race, or disease specificity to particular host species genotypes, is one character that may or may not correlate with clonal lineage. In F. oxysporum f. sp. cubense (R. Koenig, R. C. Ploetz, and H. C. Kistler, unpublished data), races of the pathogen did partition nonrandomly into particular clonal lineages as they do for races of the rice blast pathogen Magnaporthe grisea $(62,63,95)$. Similarly, races aligned with VCGs and DNA fingerprint patterns in $F$. oxysporum f. sp. dianthi (65). However, in other well-studied forma speciales, races were dispersed among clonal lineages of the pathogen. Races 1 and 2 of $F$. oxysporum f. sp. lycopersici were distributed seemingly at random to all lineages containing either VCG 0030, 0031, 0032, or 003- (24). Also, a single clonal lineage of $F$. oxysporum f. sp. melonis contained all known races of the pathogen $(33,40)$. These results have been interpreted to mean that race determinants are simple (33) and/or race determinants are highly mutable (24). Although these interpretations are probably correct in many instances, race determinants also may exist in a heterogeneous state in pathogen lineages, and this heterogeneity could be maintained by selection in response to local environmental conditions or host genotypes.

\section{Future Questions to be Addressed by Population Genetics}

Future population studies should test whether recombination, sexual or asexual, can be detected in the field. Parasexual recombination between strains of $F$. oxysporum has been observed in the laboratory (75) but has yet to be demonstrated in nature. Although most available information points to strict clonal reproduction in the species, it is still unknown whether this results from obligate asexuality or other factors such as epidemic population structure. Even a fungus that may undergo sexual reproduction can appear clonal if isolates are sampled from a particular "population explosion" of clones from a successful genotype involved in a disease epidemic (32). Pairwise tests of linkage disequilibrium or the multilocus index of association can provide statistical support for clonal population structure (87), but these methods have yet to be widely applied to population studies of $F$. oxysporum. Clone-corrected measures of disequilibrium also can detect recombination in a background otherwise dominated by the effect of resampling clones (69).

Most genetic diversity studies on $F$. oxysporum have focused on preexisting subspecific categories such as VCG and race. With a few outstanding exceptions $(3,35,36)$, isolates have been collected with little regard to the details of spatial distribution. In the future, hierarchical sampling of further populations will be needed to test the level of diversity among isolates within the same plant, field, or local geographic region. Sampling a soilborne pathogen directly from soil is difficult, but the task is even more laborious for $F$. oxysporum due to the presence of numerous nonpathogenic isolates in the soil, rhizosphere, or even healthy roots. However, Gordon et al. (36) sampled $F$. oxysporum isolates without regard to pathogenicity and compared genetic diversity, based on mtDNA haplotypes, between cultivated and adjacent native soils in California. They found that no differences in diversity could be attributed to soil type, but a significant portion of the genetic diversity in the native soil was attributed to the individual sample locations within that site. Therefore, genetic diversity seemed unevenly distributed within the undisturbed native soil. Determining the distribution of particular pathogenic genotypes of F. oxysporum in agricultural soils will be possible using similar methods.

The effect of plant cultivar on the profile of isolates recovered from the field should be assessed. Sampling pathogen populations may establish host preference or selectivity of genotypes and the potential for cultivars to have long-term effects on the composition of the pathogen population. Future work, therefore, should concentrate on how populations of $F$. oxysporum change over time and the factors that influence that change. Undoubtedly, the presence or absence of host plants and the effect of the genotype of host plants will be important factors to consider.

The study of the mechanisms by which genetic change occurs in $F$. oxysporum also will be important. Many of the expectations of population analysis are dependent on assumptions about mechanisms of reproduction and genetic change. For example, the HardyWeinberg model of populations is based on assumptions of Mendelian genetics, random mating, and negligible mutation rate. Clonal models focus on mutation rate with negligible genetic exchange among clones. Obviously, reproductive habits and mechanisms available for genetic change greatly affect the structure of populations in nature. The mechanisms available for genetic change in $F$. oxysporum are still largely unknown, but numerous possibilities exist beyond simple sexual or clonal reproduction (55). F. oxysporum has proven to be a wellhead of diversity for active fungal transposable elements $(2,17-19,44,58)$. Transposons may comprise up to $5 \%$ of the $F$. oxysporum genome and, thus, may have a profound impact on gene structure and function as well as the overall chromosomal makeup of the species (17). Perhaps not coincidentally, analysis of EK of $F$. oxysporum $(11,74,76)$ indicates a higher level of variation than for other species of Fusarium (94). Studies of $F$. oxysporum also suggest a degree of genetic duplication in the nuclear regions containing genes for rRNAs (5, $11,25,80)$ and even for dispersed sequences detected by random, anonymous, "single-copy" clones (53). Although usually presumed to be haploid, the small amount of data currently available suggest that many strains are aneuploid. Genetic evidence consistent with horizontal genetic transfer (17) and past genetic hybridization between lineages $(5,80)$ indicate that mechanisms for recombination and production of novel genotypes are available. How these factors may influence the population dynamics and evolution of the fungus demand further attention.

\section{ADDENDUM}

This review was completed in September 1995 and, thus, does not cover information published subsequently. The reader is directed to two more recent publications that have significant bearing on the issues discussed here. The first is Waalwijk, et al. (Mycologia. 1996. 88:361-368), which discusses, among other matters, the relationship between $F$. oxysporum and $F$. redolens and how this may explain the results of Donaldson et al. (20) with regard to their finding two distinct forms of $F$. oxysporum. The second is an excellent review by M. Milgroom on analysis of recombination and population structure in fungal plant pathogens (Annu. Rev. Phytopathol. 1996. 34:457-477). The review outlines experimental approaches to many of the questions raised here.

\section{ACKNOWLEDGMENTS}

Support was provided by the U.S. Agency for International Development Grant COM-5600-G-00-0023-0, and continuing support was provided by BARD, the United States-Israel Binational Agricultural Research and Development Fund, and the National Research Initiative of the U.S. Department of Agriculture. Florida Journal Series R-04774. I thank D. Fernandez, T. Gordon, J. Katan, T. Katan, K. O'Donnell, and R. Ploetz for discussion and helpful comments. Thanks also to the many scientists who supplied unpublished information for inclusion in this review.

\section{LITERATURE CITED}

1. Aloi, C., and Baayen, R. P. 1993. Examination of the relationships between vegetative compatibility groups and races in Fusarium oxysporum f. sp. dianthi. Plant Pathol. 42:839-850.

2. Anaya, N., and Roncero, M. I. G. 1995. Skippy, a retrotransposon from 
the fungal plant pathogen Fusarium oxysporum. Mol. Gen. Genet. 249: 637-647.

3. Appel, D. J., and Gordon, T. R. 1994. Local and regional variation in populations of Fusarium oxysporum from agricultural field soils. Phytopathology 84:786-791.

4. Appel, D. J., and Gordon, T. R. 1995. Intraspecific variation within populations of Fusarium oxysporum based on RFLP analysis of the intergenic spacer region. Exp. Mycol. 19:120-128.

5. Appel, D. J., and Gordon, T. R. 1996. Relationships among pathogenic and nonpathogenic isolates of Fusarium oxysporum based on the partial sequence of the intergenic spacer region of the ribosomal DNA. Mol. Plant-Microbe Interact. 9:125-138.

6. Armstrong, G. M., and Armstrong, J. K. 1966. Races of Fusarium oxysporum f. sp. conglutinans; race 4, new race; and a new host for race 1, Lychnis chalcedonica. Phytopathology 56:525-530.

7. Armstrong, G. M., and Armstrong, J. K. 1981. Formae speciales and races of Fusarium oxysporum causing wilt diseases. Pages 391-399 in: Fusarium: Diseases, Biology and Taxonomy. P. E. Nelson, T. A. Toussoun, and R. J. Cook, eds. The Pennsylvania State University Press, University Park.

8. Assigbetse, K. B., Fernandez, D., Dubois, M. P., and Geiger, J.-P. 1994. Differentiation of Fusarium oxysporum $\mathrm{f}$. sp. vasinfectum races on cotton by random amplified polymorphic DNA (RAPD) analysis. Phytopathology 84:622-626.

9. Bentley, S., Pegg, K. G., and Dale, J. L. 1995. Genetic variation among a world-wide collection of isolates of Fusarium oxysporum f. sp. cubense analysed by RAPD-PCR fingerprinting. Mycol. Res. 99:1378-1384.

10. Bodker, L., Lewis, B. G., and Coddington, A. 1993. The occurrence of a new genetic variant of Fusarium oxysporum f. sp. pisi. Plant Pathol. 42: 833-838.

11. Boehm, E. W. A., Ploetz, R. C., and Kistler, H. C. 1994. Statistical analysis of electrophoretic karyotype variation among vegetative compatibility groups of Fusarium oxysporum f. sp. cubense. Mol. Plant-Microbe Interact. 7:196-207.

12. Booth, C. 1971. The Genus Fusarium. Commonwealth Mycological Institute, Kew, England.

13. Bosland, P. W., and Williams, P. H. 1987. An evaluation of Fusarium oxysporum from crucifers based on pathogenicity, isozyme polymorphism, vegetative compatibility, and geographic origin. Can. J. Bot. 65: 2067-2073.

14. Bosland, P. W., and Williams, P. H. 1988. Pathogenicity of geographic isolates of Fusarium oxysporum from crucifers on a differential set of crucifer seedlings. J. Phytopathol. 123:63-68.

15. Bruns, T. D., White, T. J., and Taylor, J. W. 1991. Fungal molecular systematics. Annu. Rev. Ecol. Sys. 22:525-564.

16. Coddington, A., Matthews, P. M., Cullis, C., and Smith, K. H. 1987. Restriction digest patterns of total DNA from different races of Fusarium oxysporum f. sp. pisi-An improved method for race classification. J. Phytopathol. 118:9-20.

17. Daboussi, M. J., and Langin, T. 1994. Transposable elements in the fungal plant pathogen Fusarium oxysporum. Genetica 93:49-59.

18. Daboussi, M. J., Langin, T., and Brygoo, Y. 1992. Fot1, a new family of fungal transposable elements. Mol. Gen. Genet. 232:12-16.

19. Di Pietro, A., Anaya, N., and Roncero, M. I. G. 1994. Occurrence of a retrotransposon-like sequence among different formae speciales and races of Fusarium oxysporum. Mycol. Res. 98:993-996.

20. Donaldson, G. C., Ball, L. A., Axelrood, P. E., and Glass, N. L. 1995. Primer sets developed to amplify conserved genes from filamentous ascomycetes are useful in differentiating Fusarium species associated with conifers. Appl. Environ. Microbiol. 61:1331-1340.

21. Edel, V., Steinberg, C., Avelange, I., Laguerre, G., and Alabouvette, C. 1995. Comparison of three molecular methods for the characterization of Fusarium oxysporum strains. Phytopathology 85:579-585.

22. Elias, K. S., and Schneider, R. W. 1991. Vegetative compatibility groups in Fusarium oxysporum f. sp. lycopersici. Phytopathology 81:159-162.

23. Elias, K. S., and Schneider, R. W. 1992. Genetic diversity within and among races and vegetative compatibility groups of Fusarium oxysporum f. sp. lycopersici as determined by isozyme analysis. Phytopathology 82:1421-1427.

24. Elias, K. S., Zamir, D., Lichtman-Pleban, T., and Katan, T. 1993. Population structure of Fusarium oxysporum f. sp. lycopersici: Restriction fragment length polymorphisms provide genetic evidence that vegetative compatibility group is an indicator of evolutionary origin. Mol. PlantMicrobe Interact. 6:565-572.

25. Fekete, C., Nagy, R., Debets, A. J. M., and Hornok, L. 1993. Electrophoretic karyotypes and gene mapping in eight species of the Fusarium sections Arthrosporiella and Sporotrichiella. Curr. Genet. 24:500-504.

26. Fernandez, D., Assigbetse, K., Dubois, M.-P., and Geiger, J.-P. 1994. Molecular characterization of races and vegetative compatibility groups in Fusarium oxysporum f. sp. vasinfectum. Appl. Environ. Microbiol. 60:
4039-4046.

27. Fernandez, D., Ouinten, M., Tantaoui, A., Lourd, M., and Geiger, J.-P. 1995. Population genetic structure of Fusarium oxysporum f. sp. albedinis. (Abstr.) Fungal Genet. Newsl. 42A:34.

28. Fernandez, D., and Tantaoui, A. 1994. Random amplified polymorphic DNA (RAPD) analysis: A tool for rapid characterization of Fusarium oxysporum f. sp. albedinis isolates? Phytopathol. Mediterr. 33:223-229.

29. Flood, J., Whitehead, D. S., and Cooper, R. M. 1992. Vegetative compatibility and DNA polymorphisms in Fusarium oxysporum f. sp. elaeidis and their relationship to isolate virulence and origin. Physiol. Mol. Plant Pathol. 41:201-215.

30. Glass, N. L., and Donaldson, G. C. 1995. Development of primer sets designed for use with the PCR to amplify conserved genes from filamentous ascomycetes. Appl. Environ. Microbiol. 61:1323-1330.

31. Glass, N. L., and Kuldau, G. A. 1992. Mating type and vegetative incompatibility in filamentous ascomycetes. Annu. Rev. Phytopathol. 30: 201-224.

32. Goodwin, S. B., Cohen, B. A., and Fry, W. E. 1994. Panglobal distribution of a single clonal lineage of the Irish potato famine fungus. Proc. Natl. Acad. Sci. USA 91:11591-11595.

33. Gordon, T. R. 1993. Genetic variation and adaptive potential in an asexual soilborne fungus. Pages 217-224 in: The Fungal Holomorph: Mitotic, Meiotic and Pleomorphic Speciation in Fungal Systematics. D. R. Reynolds and J. W. Taylor, eds. CAB International, Wallingford, England.

34. Gordon, T. R., and Okamoto, D. 1992. Variation within and between populations of Fusarium oxysporum based on vegetative compatibility and mitochondrial DNA. Can. J. Bot. 70:1211-1217.

35. Gordon, T. R., and Okamoto, D. 1992. Population structure and the relationship between pathogenic and nonpathogenic strains of Fusarium oxysporum. Phytopathology 82:73-77.

36. Gordon, T. R., Okamoto, D., and Milgroom, M. G. 1992. The structure and interrelationship of fungal populations in native and cultivated soils. Mol. Ecol. 1:241-249.

37. Grajal-Martín, M. J., Simon, C. J., and Muehlbauer, F. J. 1993. Use of random amplified polymorphic DNA (RAPD) to characterize race 2 of Fusarium oxysporum f. sp. pisi. Phytopathology 83:612-614.

38. Guadet, J., Julien, J., Lafay, J. F., and Brygoo, Y. 1989. Phylogeny of some Fusarium species, as determined by large-subunit rRNA sequence comparison. Mol. Biol. Evol. 6:227-242.

39. Hirota, N., Hashiba, T., Yoshida, H., Kikumoto, T., and Ehara, Y. 1992. Detection and properties of plasmid-like DNA in isolates from twentythree formae speciales of Fusarium oxysporum. Ann. Phytopathol. Soc. Jpn. 58:386-392.

40. Jacobson, D. J., and Gordon, T. R. 1988. Vegetative compatibility and self-incompatibility within Fusarium oxysporum f. sp. melonis. Phytopathology 78:668-672.

41. Jacobson, D. J., and Gordon, T. R. 1990. Further investigations of vegetative compatibility within Fusarium oxysporum f. sp. melonis. Can. J. Bot. 68:1245-1248.

42. Jacobson, D. J., and Gordon, T. R. 1990. Variability of mitochondrial DNA as an indicator of relationships between populations of Fusarium oxysporum f. sp. melonis. Mycol. Res. 94:734-744.

43. Jones, J. P., and Woltz, S. S. 1981. Fusarium-incited diseases of tomato and potato and their control. Pages 157-168 in: Fusarium: Diseases, Biology and Taxonomy. P. E. Nelson, T. A. Toussoun and R. J. Cook, eds. The Pennsylvania State University Press, University Park.

44. Julien, J., Poirier-Hamon, S., and Brygoo, Y. 1992. Foret1, a reverse transcriptase-like sequence in the filamentous fungus Fusarium oxysporum. Nucleic Acids Res. 20:3933-3937.

45. Katan, J. 1971. Symptomless carriers of the tomato Fusarium wilt pathogen. Phytopathology 61:1213-1217.

46. Katan, T., Hadar, E., and Katan, J. 1989. Vegetative compatibility of $F u$ sarium oxysporum f. sp. dianthi from carnation in Israel. Plant Pathol. 38: 376-381.

47. Katan, T., and Katan, J. 1988. Vegetative-compatibility grouping of $F u$ sarium oxysporum f. sp. vasinfectum from tissue and the rhizosphere of cotton plants. Phytopathology 78:852-855

48. Katan, T., Katan, J., Gordon, T. R., and Pozniak, D. 1994. Physiologic races and vegetative compatibility groups of Fusarium oxysporum f. sp. melonis in Israel. Phytopathology 84:153-157.

49. Katan, T., Zamir, D., Sarfatti, M., and Katan, J. 1991. Vegetative compatibility groups and subgroups in Fusarium oxysporum f. sp. radicislycopersici. Phytopathology 81:255-262.

50. Kim, D. H., Martyn, R. D., and Magill, C. W. 1992. Restriction fragment length polymorphism groups and physical map of mitochondrial DNA from Fusarium oxysporum f. sp. niveum. Phytopathology 82:346-353.

51. Kim, D. H., Martyn, R. D., and Magill, C. W. 1993. Chromosomal polymorphism in Fusarium oxysporum f. sp. niveum. Phytopathology 83: 1209-1216. 
52. Kistler, H. C., and Benny, U. 1989. The mitochondrial genome of $F u$ sarium oxysporum. Plasmid 22:86-89.

53. Kistler, H. C., Benny, U., Boehm, E. W. A., and Katan, T. 1995. Genetic duplication in Fusarium oxysporum. Curr. Genet. 28:173-176.

54. Kistler, H. C., Bosland, P. W., Benny, U., Leong, S., and Williams, P. H. 1987. Relatedness of strains of Fusarium oxysporum from crucifers measured by examination of mitochondrial and ribosomal DNA. Phytopathology 77:1289-1293.

55. Kistler, H. C., and Miao, V. P. W. 1992. New modes of genetic change in filamentous fungi. Annu. Rev. Phytopathol. 30:131-152.

56. Kistler, H. C., Momol, E. A., and Benny, U. 1991. Repetitive genomic sequences for determining relatedness among strains of Fusarium oxysporum. Phytopathology 81:331-336.

57. Koenig, R. L., Kistler, H. C., and Ploetz, R. C. 1993. Restriction fragment length polymorphism analysis of Fusarium oxysporum f. sp. cubense. Page 158 in: 6th Int. Congr. Plant Pathol. National Research Council of Canada, Ottawa, ON.

58. Langin, T., Capy, P., and Daboussi, M.-J. 1995. The transposable element impala, a fungal member of the Tcl-mariner superfamily. Mol. Gen. Genet. 246:19-28.

59. Larkin, R. P., Hopkins, D. L., and Martin, F. N. 1990. Vegetative compatibility within Fusarium oxysporum f. sp. niveum and its relationship to virulence, aggressiveness, and race. Can. J. Microbiol. 36:352-358.

60. Leslie, J. F. 1991. Mating populations in Gibberella fujikuroi (Fusarium section Liseola). Phytopathology 81:1058-1060.

61. Leslie, J. F. 1993. Fungal vegetative compatibility. Annu. Rev. Phytopathol. 31:127-150.

62. Levy, M., Correa-Victoria, F. J., Zeigler, R. S., Xu, S., and Hamer, J. E. 1993. Genetic diversity of the rice blast fungus in a disease nursery in Colombia. Phytopathology 83:1427-1433.

63. Levy, M., Romao, J., Marchetti, M. A., and Hamer, J. E. 1991. DNA fingerprinting with a dispersed repeated sequence resolves pathotype diversity in the rice blast fungus. Plant Cell 3:95-102.

64. Lynch, M., and Milligan, B. G. 1995. Analysis of population genetic structure with RAPD markers. Mol. Ecol. 3:91-99.

65. Manicom, B. Q., and Baayen, R. P. 1993. Restriction fragment length polymorphisms in Fusarium oxysporum f. sp. dianthi and other fusaria from Dianthus species. Plant Pathol. 42:851-857.

66. Manicom, B. Q., Bar-Joseph, M., Kotze, J. M., and Becker, M. M. 1990. A restriction fragment length polymorphism probe relating vegetative compatibility groups and pathogenicity in Fusarium oxysporum f. sp. dianthi. Phytopathology 80:336-339.

67. Manulis, S., Kogan, N., Reuven, M., and Ben-Yephet, Y. 1994. Use of the RAPD technique for identification of Fusarium oxysporum f. sp. dianthi from carnation. Phytopathology 84:98-101.

68. McDermott, J. M., and McDonald, B. A. 1993. Gene flow in plant pathosystems. Annu. Rev. Phytopathol. 31:353-373.

69. McDonald, B. A., Pettway, R. E., Chen, R. S., Boeger, J. M., and Martinez, J. P. 1995. The population genetics of Septoria tritici (teleomorph Mycosphaerella graminicola). Can. J. Bot. 73 (Suppl. 1A-D): S292-S301.

70. Menzies, J. G., Koch, C., and Seywerd, F. 1990. Additions to the host range of Fusarium oxysporum f. sp. radicis-lycopersici. Plant Dis. 74:569-572.

71. Mes, J. J., Van Doorn, J., Roebroeck, E. J. A., and Boonekamp, P. M. 1995. Detection and identification of Fusarium oxysporum f. sp. gladioli by RFLP and RAPD analysis. Pages 63-68 in: Modern Assays for Plant Pathogenic Fungi: Identification, Detection and Quantification. A. Schots, F. M. Dewey, and R. Oliver, eds. CAB International, Wallingford, England.

72. Mes, J. J., Van Doorn, J., Roebroeck, E. J. A., Van Egmond, E., Van Aartrijk, J., and Boonekamp, P. M. 1994. Restriction fragment length polymorphisms, races and vegetative compatibility groups within a worldwide collection of Fusarium oxysporum f. sp. gladioli. Plant Pathol. 43:362-370.

73. Miao, V. P. W. 1990. Using karyotype variability to investigate the origins and relatedness of isolates of Fusarium oxysporum f. sp. cubense. Pages 55-62 in: Fusarium Wilt of Banana. R. C. Ploetz, ed. The Ameri- can Phytopathological Society, St. Paul, MN

74. Migheli, Q., Berio, T., Gullino, M. L., and Garibaldi, A. 1995. Electrophoretic karyotype variation among pathotypes of Fusarium oxysporum f. sp. dianthi. Plant Pathol. 44:308-315.

75. Molnar, A., Sulyok, L., and Hornok, L. 1990. Parasexual recombination between vegetatively incompatible strains in Fusarium oxysporum. Mycol. Res. 94:393-398.

76. Momol, E. A., and Kistler, H. C. 1992. Mitochondrial plasmids do not determine host range in crucifer-infecting strains of Fusarium oxysporum. Plant Pathol. 41:103-112.

77. Namiki, F., Shiomi, T., Kayamura, T., and Tsuge, T. 1994. Characterization of the formae speciales of Fusarium oxysporum causing wilts of cucurbits by DNA fingerprinting with nuclear repetitive DNA sequences. Appl. Environ. Microbiol. 60:2684-2691.

78. Nelson, P. E. 1991. History of Fusarium systematics. Phytopathology 81:1045-1051

79. O’Donnell, K. 1992. Ribosomal DNA internal transcribed spacers are highly divergent in the phytopathogenic ascomycete Fusarium sambucinum (Gibberella pulicaris). Curr. Genet. 22:213-220.

80. O'Donnell, K., and Cigelnik, E. 1997. Two divergent intragenomic rDNA ITS 2 types within a monophyletic lineage of the fungus Fusarium are non-orthologous. Mol. Phylo. Evol. 1:1-14.

81. Pérez-Artés, E., Roncero, M. I. G., and Jiménez-Díaz, R. M. 1995. Restriction fragment length polymorphism analysis of the mitochondrial DNA of Fusarium oxysporum f. sp. ciceris. J. Phytopathol. 143:105-109.

82. Ploetz, R. C. 1990. Variability in Fusarium oxysporum f. sp. cubense. Can. J. Bot. 68:1357-1363.

83. Ploetz, R. C., and Correll, J. C. 1988. Vegetative compatibility among races of Fusarium oxysporum f. sp. cubense. Plant Dis. 72:325-328.

84. Puhalla, J. E. 1985. Classification of strains of Fusarium oxysporum on the basis of vegetative compatibility. Can. J. Bot. 63:179-183.

85. Ramirez-Villupadua, J., Endo, R. M., Bosland, P., and Williams, P. H. 1985. A new race of Fusarium oxysporum f. sp. conglutinans that attacks cabbage with type A resistance. Plant Dis. 69:612-613.

86. Rowe, R. C. 1980. Comparative pathogenicity and host ranges of $F u$ sarium oxysporum isolates causing crown and root rot of greenhouse and field-grown tomatoes in North America and Japan. Phytopathology 70: 1143-1148.

87. Smith, J. M., Smith, N. H., O’Rourke, M., and Spratt, B. G. 1993. How clonal are bacteria? Proc. Natl. Acad. Sci. USA 90:4384-4388.

88. Snyder, W. C., and Hansen, H. N. 1940. The species concept in Fusarium. Am. J. Bot. 27:64-67.

89. Stall, R. E., and Walter, J. M. 1965. Selection and inheritance of resistance in tomato to isolates of races 1 and 2 of the Fusarium wilt organism. Phytopathology 55:1213-1215.

90. Tantaoui, A., and Fernandez, D. 1993. Comparaison entre Fusarium oxysporum f. sp. albedinis et Fusarium oxysporum des sols de palmeraies par l'etude du polymorphisme de longueur des fragments de restriction (RFLP). Phytopathol. Mediterr. 32:235-244.

91. Whitehead, D. S., Coddington, A., and Lewis, B. G. 1992. Classification of races by DNA polymorphism analysis and vegetative compatibility grouping in Fusarium oxysporum f. sp. pisi. Physiol. Mol. Plant Pathol. 41:295-305.

92. Wollenweber, H. W., and Reinking, O. A. 1935. Die Fusarien, Ihre Beschreibung, Schadwirkung und Bekampfung. P. Parey, Berlin.

93. Woudt, L. P., Neuvel, A., Sikkema, A., van Grinsven, M. Q. J. M., de Milliano, W. A. J., Campbell, C. L., and Leslie, J. F. 1995. Genetic variation in Fusarium oxysporum from cyclamen. Phytopathology 85:1348-1355.

94. Xu, J.-R., Yan, K., Dickman, M. B., and Leslie, J. F. 1995. Electrophoretic karyotypes distinguish the biological species of Gibberella fujikuroi (Fusarium section Liseola). Mol. Plant-Microbe Interact. 8:74-84.

95. Zeigler, R. S., Cuoc, L. X., Scott, R. P., Bernardo, M. A., Chen, D. H., Valent, B., and Nelson, R. J. 1995. The relationship between lineage and virulence in Pyricularia grisea in the Philippines. Phytopathology 85: 443-451. 